\title{
Diplomasi Budaya Jepang dan Korea Selatan di Indonesia Tahun 2020: Studi Komparasi
}

\author{
Annisa Nur Islamiyah, Nafila Maulina Priyanto, dan \\ Ni Putu Dyana Prabhandari \\ Universitas Pembangunan Nasional "Veteran” Jawa Timur
}

\begin{abstract}
ABSTRAK
Produk industri kreatif, yang masuk dalam kategori produk kebudayaan, merupakan salah satu instrumen soft power yang dapat berpengaruh terhadap pembuatan kebijakan. Jepang dan Korea Selatan merupakan dua negara yang telah melakukan strategi internasionalisasi terhadap produk industri kreatif mereka untuk meningkatkan perekonomian. Selain menjadi sektor yang berkontribusi dalam perekonomian, melalui Korean Hallyu dan Cool Japan, industri kreatif Jepang dan Korea Selatan telah menjadi instrumen diplomasi budaya yang bertujuan untuk memengaruhi opini publik terhadap kedua negara tersebut. Di Indonesia, perbedaan pada strategi pengembangan yang dilakukan kedua negara berpengaruh terhadap kesuksesan diplomasi budaya yang dilakukan. Penelitian ini bertujuan untuk mengidentifikasi perbedaan antara strategi yang dilakukan Jepang dan Korea Selatan dalam melakukan pendekatan diplomasi budaya di Indonesia. Penelitian ini menemukan bahwa diplomasi budaya yang dilakukan Jepang kurang sukses karena strategi internasionalisasinya kurang memasukkan nilai-nilai budaya di dalamnya, dan karena kurangnya dukungan pemerintah terhadap industri kreatif.
\end{abstract}

\section{Kata-kata Kunci: Diplomasi Budaya, Korean Hallyu, Cool Japan}

Products of the creative industry, which falls under the category of cultural products, represent one of soft power instruments capable of influencing policy-making processes. Japan and South Korea are two states that have implemented internationalization strategies on their creative industry products in order to boost economy. In addition to becoming sectors that contribute to the economy, by the means of the Korean Hallyu and Cool Japan, the creative industries of Japan and South Korea have become instruments of cultural diplomacy aimed at influencing public opinions on both states. In Indonesia, differences in the development strategies implemented by both states have influenced the degree of success in their cultural diplomacy. This research aims to identify differences between the strategies implemented by Japan and South Korea in conducting cultural diplomacy in Indonesia. This research has found that the cultural diplomacy conducted by Japan has been less successful due to the lack of incorporation of cultural values in its internationalization strategy, as well as the lack of government support for its creative industry.

Keywords: Cultural Diplomacy, Korean Hallyu, Cool Japan 
Sebagai aktor utama dalam hubungan internasional dalam teori realis, negara memiliki identitas yang membedakan dirinya dari negara-negara lain. Budaya merupakan salah satu bentuk identitas yang dimiliki oleh negara. Pada tingkat internasional, budaya dapat dijadikan instrumen kebijakan luar negeri negara. Dua negara yang dapat menjadi contoh menarik dari penggunaan budaya sebagai instrumen kebijakan luar negeri adalah Jepang dan Korea Selatan. Meskipun Jepang dan Korea Selatan dapat dikategorikan sebagai negara maju dengan teknologi tinggi, ternyata kedua negara masih menggunakan budaya sebagai salah satu strategi diplomasinya. Tidak hanya di kawasan Asia Timur, di kawasan Asia Tenggara budaya Jepang dan Korea juga menunjukkan pengaruh yang sangat kental. Pengaruh budaya tersebut dikarenakan kawasan Asia Tenggara juga menjadi target utama kedua negara dalam melakukan diplomasi budaya. Indonesia juga merupakan salah satu negara Asia Tenggara yang menjadi negara tujuan.

Di Indonesia, Jepang melakukan diplomasi budaya melalui anime dan manga. Hal ini terbukti dengan banyaknya anime Jepang yang ditampilkan pada siaran televisi nasional. Manga merupakan istilah komik dalam bahasa Jepang. Istilah manga pertama kali digunakan pada tahun 1989 untuk menggambarkan buku Shiji Ada Yukikai (Wood 2017). Melihat peningkatan popularitas manga secara global, pemerintah Jepang kemudian mulai mendorong pengembangan sektor ini dengan mendirikan School of Cartoon and Comic Art, sebuah sekolah khusus yang berfokus pada seni membuat manga (Ito 2005). Selain manga dan anime, J-Pop dan drama Jepang juga menjadi alat diplomasi yang digunakan oleh Jepang. Namun, di Indonesia J-Pop dan drama Jepang tidak begitu populer karena beberapa faktor, salah satunya adalah kurangnya dukungan dari pemerintah dalam sektor industri musik Jepang (Efendi 2012).

Tidak hanya Jepang, Korea Selatan juga menggunakan budaya sebagai instrumen diplomasinya. Di Indonesia, Korea Selatan menggunakan Korean Wave atau Hallyu sebagai instrumen diplomasinya. Korean Wave merupakan istilah yang digunakan untuk mendeskripsikan produk-produk kebudayaan Korea Selatan seperti acara televisi, seri drama, film, musik, tari-tarian modern, makanan, bahasa, video game, hingga produk kecantikan (Jang dan Paik 2012). Diplomasi yang dilakukan oleh Korea Selatan bertujuan untuk membangun citra Korea Selatan yang modern. Selain itu, Hallyu merupakan produk kebudayaan Korea Selatan yang memang digunakan oleh pemerintah sebagai instrumen penyebaran budaya di dunia. Penyebaran budaya yang dilakukan dengan diplomasi ini digunakan pemerintah Korea Selatan sebagai upaya untuk 
meningkatkan perkembangan dan pertumbuhan ekonomi. Korean Wave dan Hallyu digunakan oleh pemerintah Korea Selatan sebagai instrumen kebijakan luar negeri untuk membantu diplomasi publik dan diplomasi budaya Korea Selatan.

Penyebaran budaya Korea Selatan dengan menggunakan instrumen Hallyu ini dimulai sejak tahun 2002, yakni sejak piala dunia berhasil dilakukan di Jepang dan Korea Selatan. Sejak peristiwa tersebut, mulai banyak serial drama Korea yang berhasil masuk dan bahkan ditayangkan di televisi nasional Indonesia. Masuknya K-Drama di Indonesia ini diikuti dengan masuknya industri musik Korea Selatan, yang biasa disebut dengan K-Pop. Sejak tahun 2011, industri kreatif Korea Selatan semakin berpengaruh di Indonesia dan pada tahun 2012 konser artis Korea Selatan Super Junior dilaksanakan di Indonesia untuk pertama kalinya. Peristiwa ini menandakan besarnya peminat musik K-Pop di Indonesia.

Dengan penjabaran tersebut, terlihat bahwa Jepang dan Korea Selatan menggunakan diplomasi budaya sebagai salah satu instrumen untuk meningkatkan citra negara di Indonesia. Namun, periode popularitas keduanya berbeda. Budaya Jepang populer di Indonesia sejak sebelum tahun 2000 hingga awal dekade 2000-an. Namun, kemudian popularitas budaya Jepang digantikan dengan popularitas budaya Korea Selatan. Penulis melihat penurunan popularitas budaya Jepang dan peningkatan popularitas budaya Korea Selatan di Indonesia sebagai fenomena yang menarik. Oleh karena itu, penulis menganalisis tingkat kesuksesan diplomasi budaya yang dilakukan oleh Jepang dan Korea Selatan dengan mengangkat judul Diplomasi Budaya Jepang dan Korea Selatan di Indonesia: Studi Komparasi, yang bertujuan untuk menganalisis naik-turunnya popularitas budaya Jepang dan Korea Selatan di Indonesia.

\section{Definisi Konseptual dan Metodologi}

Globalisasi telah menjadikan peran media sosial lebih penting. Hal ini dibuktikan dengan adanya internet, yang menimbulkan proses demokratisasi distribusi informasi dengan cara-cara baru (Goff 2013). Dengan adanya fenomena informasi yang mengalir sangat deras tanpa adanya lintas batas ternyata juga berdampak pada praktik diplomasi (Goff, 2013). Diplomasi publik pertama kali muncul pada tahun 1965 bertepatan pada proses internasionalisasi informasi dan relasi antarkebudayaan (Cull 2009). Proses globalisasi telah mempermudah praktik diplomasi publik. Dengan derasnya pertukaran informasi sebagai dampak dari globalisasi, 
diplomasi publik memeroleh peluang lebih besar untuk berhasil dalam mencapai tujuannya untuk memeroleh perhatian audiens sebagai salah satu upaya pemerintah dalam mendukung kebijakan luar negeri.

Menurut Tuch (1990), diplomasi publik dilakukan dengan tujuan untuk memberikan pemahaman mengenai gagasan-gagasan dan cita-cita negara. Dalam pelaksanaannya, diplomasi publik bersifat government-driven, yang artinya pemerintah memegang kendali besar dalam pelaksanaan diplomasi publik. Perhatian dari publik negara-negara asing merupakan tujuan utama dari diplomasi publik. Menurut Nye (2008), diplomasi publik dilakukan oleh pemerintah untuk memobilisasi sumber-sumber daya tarik yang dimiliki agar dapat berkomunikasi dan menarik perhatian publik asing. Diplomasi publik juga memanfaatkan informasi, budaya, dan pendidikan sebagai media dalam praktiknya. Diplomasi publik juga diartikan sebagai aktivitas-aktivitas yang dilakukan oleh pemerintah dengan melibatkan agen-agen non-negara untuk menjangkau publik dengan menggunakan informasi, budaya, dan pendidikan tersebut (Rana 2011).

Power sangat penting dalam menjalankan diplomasi publik. Seperti yang dikatakan oleh Nye (2010), supremasi-baik militer maupun ekonomi saja-tidak akan cukup untuk menjamin survivalitas negara dalam politik global era globalisasi. Pada konteks perubahan yang dipicu oleh globalisasi ini, Nye (2010) mencetuskan konsep baru yang disebut sebagai smart power. Smart Power merujuk pada kombinasi dari sifat koersif yang terdapat pada hard power dan sifat persuasif serta atraktif yang terdapat pada soft power. Diplomasi budaya merupakan salah satu contoh utama dari soft power, yang didefinisikan sebagai kemampuan untuk meyakinkan pihak lain melalui budaya, nilai-nilai, dan ide alih-alih melalui kekerasan. Dalam pelaksanaannya, diplomasi budaya memang tidak dapat diukur secara kuantitatif. Namun, kesuksesan diplomasi budaya dapat diukur dengan melihat penyebaran pengaruhnya ke negaranegara di seluruh dunia beserta interdependensi yang timbul dari penyebaran pengaruh tersebut.

Diplomasi budaya menggunakan pendekatan ideasional terhadap diplomasi dan secara bersamaan menggunakan soft power, branding, propaganda, dan diplomasi publik (Goff 2013). Jenis diplomasi ini didasarkan pada pemanfaatan pertukaran ide, nilai, tradisi, dan aspek budaya atau identitas lainnya, dengan tujuan untuk memperkuat hubungan, meningkatkan kerja sama sosial dan budaya, serta mempromosikan kepentingan nasional. Menurut 
Goff (2013), diplomasi budaya muncul dari dua premis. Premis yang pertama menyatakan bahwa hubungan baik dapat berakar pada pemahaman dan rasa hormat, sementara premis yang kedua menyatakan bahwa seni, bahasa, dan pendidikan merupakan salah satu titik masuk (entry point) paling penting ke dalam suatu budaya.

Jepang dan Korea Selatan menggunakan diplomasi budaya untuk menggunakan soft power-nya ke negara lain. Diplomasi budaya mempunyai dua kekuatan utama. Pertama, dalam praktiknya, diplomasi budaya merupakan koneksi dua arah. Artinya, tidak ada paksaan dalam pelaksanaannya, karena diplomasi budaya dilakukan berdasarkan konsensus dan keinginan setiap pihak untuk saling berhubungan. Ketika tidak terdapat paksaan, penjalinan hubungan saling percaya antarnegara akan menjadi semakin mudah. Oleh karena itu, pelaksanaan diplomasi budaya semakin diakui oleh dunia dari masa ke masa. Hal ini dibuktikan dengan tumbuhnya kesadaran negara-negara dan organisasi-organisasi internasional bahwa kebudayaan mengandung nilai-nilai yang perlu dijaga, sehingga ketika mengatasi masalah pada tingkat global, diperlukan inkorporasi elemen-elemen kebudayaan ke dalam kebijakan.

Dengan penjabaran di atas, penelitian ini menggunakan metode penelitian kualitatif dengan pendekatan studi kasus, karena pada penelitian ini peneliti ingin mengetahui perbedaan diplomasi budaya yang dilakukan oleh Jepang dan Korea Selatan di Indonesia dengan mengkomparasikan hasil keduanya. Pemilihan metode kualitatif ini bertujuan untuk menggambarkan suatu fenomena, yang dalam hal ini adalah bagaimana diplomasi budaya sebuah negara dapat berhasil dan berpengaruh pada pembangunan ekonomi. Metode penelitian kualitatif adalah salah satu prosedur penelitian yang menghasilkan data deskriptif berupa ucapan, tulisan, atau perilaku subjek yang diamati (Azwar 1998). Penelitian kualitatif diharapkan mampu menghasilkan uraian mendalam tentang ucapan, tulisan, dan/atau perilaku yang dapat diamati dari individu, kelompok, masyarakat, dan/atau organisasi tertentu dalam suatu konteks spesifik yang dikaji dari sudut pandang yang utuh, komprehensif, dan holistik. Penelitian ini menggunakan teknik pengumpulan data dengan jenis data sekunder, yang didapat secara tidak langsung dari subjek penelitian. Data sekunder merupakan data yang diperoleh dari pihak lain dan biasanya berbentuk dokumen atau laporan (Azwar 1998). Data sekunder yang diperoleh menjadi dasar untuk menjawab rumusan masalah yang telah dibuat. Maka dari itu, peneliti menggunakan situs web resmi dari Kementerian Luar Negeri Jepang dan Korea Selatan, serta dari berita-berita yang kredibel. 


\section{Diplomasi Budaya Jepang}

Jepang adalah salah satu negara yang menggunakan kekuatan politik non-militerdalamprosesnegosiasidalamsisteminternasional.Jepang memiliki budaya tradisional yang masih kental dan menggunakan sumber daya tersebut sebagai instrumen diplomasi untuk meningkatkan pengaruh politik sekaligus keuntungan ekonominya (Stanislaus 2018). Pada tahun 2010, Jepang mengenalkan program diplomasi budaya Cool Japan, yang terinspirasi dari Cool Britain milik Inggris. Dalam buku panduan diplomasi budaya (Diplomatic Bluebook) yang dijadikan acuan oleh Jepang, diplomasi budaya dilakukan dengan tujuan untuk menciptakan citra baik Jepang di negara asing, mendorong nilai produk-produk nasional jepang, dan menjalin hubungan persahabatan dengan individu-individu maupun kelompok-kelompok sehingga mereka memiliki pemahaman yang lebih baik tentang Jepang (Ministry of Foreign Affairs of Japan 2017). Produk-produk budaya yang digunakan oleh Jepang dalam diplomasi budayanya bervariasi, mulai dari budaya tadisional sampai budaya kontemporer. Produk-produk budaya tersebut antara lain meliputi: anime, manga, cosplay, J-Pop, Harajuku Street Fashion, arsitektur, dan desain.

Praktek diplomasi budaya Jepang yang secara resmi didukung oleh Kementerian Luar Negeri memang baru dilakukan sejak diluncurkannya program Cool Japan pada tahun 2010. Meskipun praktiknya kala itu belum bisa masuk dalam definisi praktik diplomasi, diseminasi budaya Jepang di wilayah Asia (utamanya kawasan Asia Tenggara) sudah dilakukan jauh sebelum itu. Di Indonesia, semisal, film atau drama Jepang sudah masuk pasar industri hiburan sejak akhir tahun 1990-an. Selain itu, festival cosplay bertaraf global, World Cosplay Summit (WCS), sudah dilakukan sejak tahun 2005 dan didukung secara resmi oleh Kementerian Luar Negeri, Kementerian Pertahanan, Infrastruktur, Dan Transportasi (Ministry of Land Infrastructure and Transport/ MLIT), dan Kementerian Ekonomi, Perdagangan dan Industri (Ministry of Economy, Trade and Industri/METI) Jepang pada tahun 2008. Selain Cosplay Summit, Jepang juga secara rutin mengadakan International Manga Award, yang diadakan untuk pertama kalinya pada tahun 2007, dan Anime Ambassador, yang dilakukan pada tahun 2008. Penyelenggaraan Anime Ambassador ini juga disertai dengan penunjukan Doraemon sebagai duta anime Jepang. Penunjukan Doraemon ditujukan untuk meningkatkan citra Jepang sebagai negara yang ramah dan "teman bagi semua", sesuai dengan ciri khas dari karakter Doraemon. 
Selain melalui budaya populer, diplomasi budaya Jepang juga dilakukan melalui kegiatan pertukaran pelajar. Kegiatan pertukaran pelajar ini ditujukan untuk memperdalam relasi yang telah dibangun antara Jepang dan negara-negara lain melalui diseminasi budaya. Pertukaran ini dilakukan dengan tiga cara, yakni: (1) menyediakan informasi mengenai kegiatan belajar di Jepang, yang juga disertai dengan pemberian kesempatan untuk belajar di Jepang bagi warga negara asing; (2) membangun relasi alumni-alumni eks-WNA pelajar Jepang; dan (3) memberikan beasiswa untuk kegiatan penelitian di Jepang bagi dosen, peneliti, maupun mahasiswa. Budaya Jepang yang akan dibahas secara spesifik dalam tulisan ini adalah budaya populer Jepang, khususnya anime, manga, J-Pop, dan drama Jepang.

\section{Diplomasi Budaya Jepang di Indonesia}

Indonesia adalah salah satu negara di kawasan Asia Tenggara yang dipengaruhi oleh budaya Jepang. Han (2015) berasumsi bahwa kesuksesan diplomasi budaya suatu negara terhadap negara lain dipengaruhi oleh persepsi negara penerima terhadap negara pelaku. Dalam hal ini, kesuksesan diplomasi budaya Jepang di Indonesia juga dipengaruhi oleh bagaimana masyarakat Indonesia melihat citra Jepang sebagai negara mitra. Untuk mengetahui hal ini, Kementerian Luar Negeri Jepang mengadakan opinion poll di enam negara (Indonesia, Filipina, Vietnam, Malaysia, Singapura, dan Thailand) di kawasan Asia Tenggara mengenai opini masyarakat negaranegara tersebut terhadap Jepang. Data di bawah ini menunjukkan tingkat reliabilitas Jepang menurut masyarakat Indonesia secara berkala pada tahun 2008 (sebelum diluncurkannya program Cool Japan), tahun 2014 (setelah diluncurkannya program Cool Japan), dan tahun 2019 (tahun terbaru) yang diperoleh dari laman resmi Kementerian Luar Negeri Jepang. 


\section{Grafik 1. Opinion Poll terhadap Jepang di Indonesia}

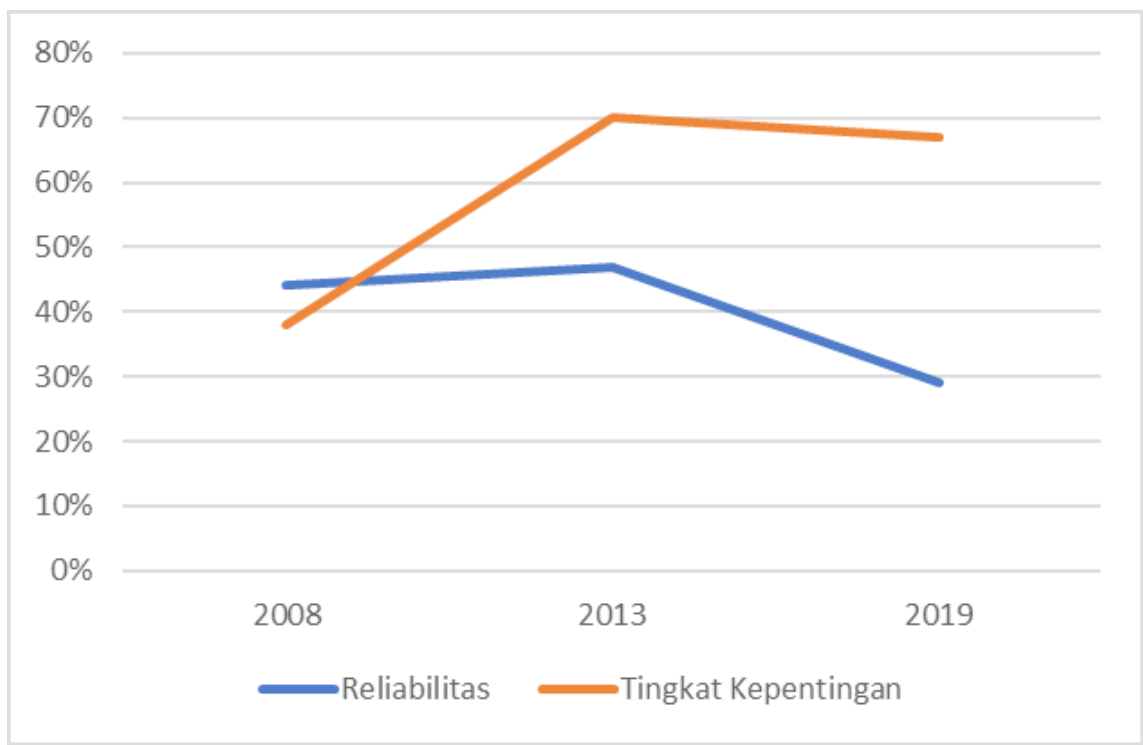

Sumber: Ministry of Foreign Affairs of Japan

Grafik 2. Opinion Polls tentang Ketertarikan Masyarakat Indonesia terhadap Budaya Jepang

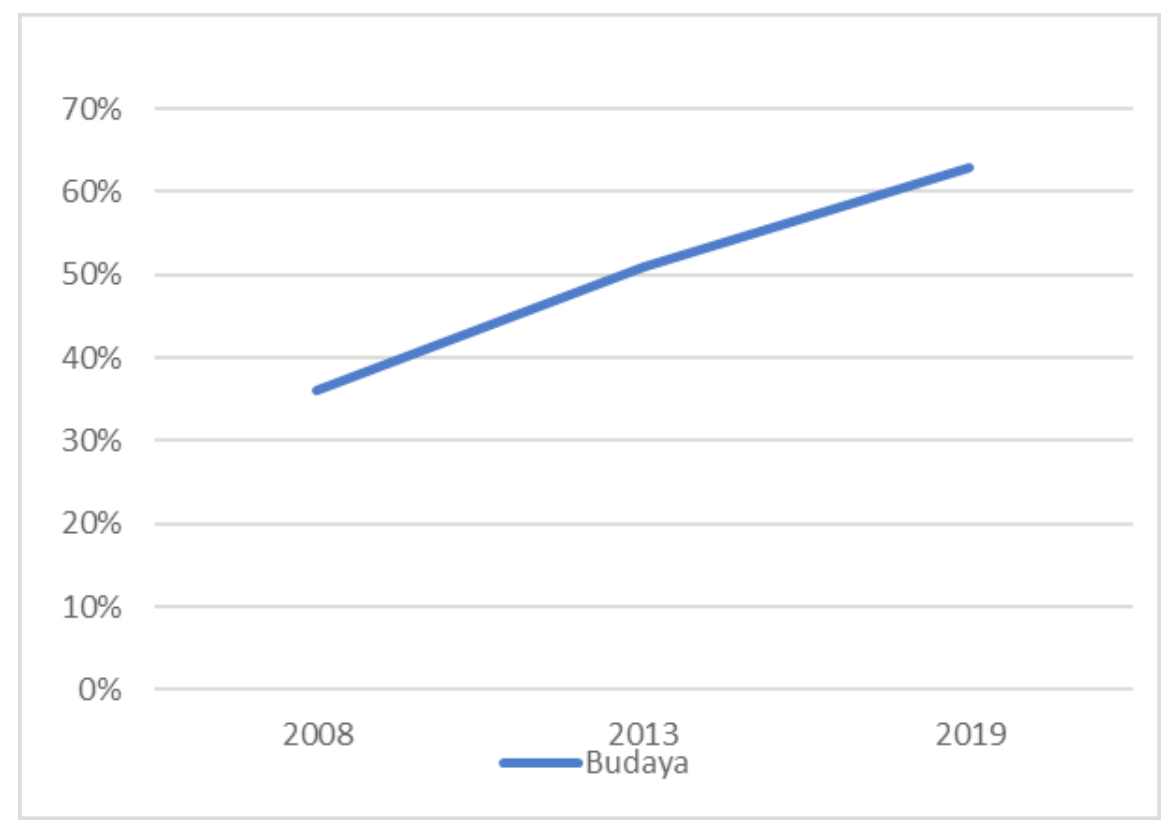

Sumber: Ministry of Foreign Affairs of Japan 


\section{Grafik 3. Tren Budaya Populer Jepang di Indonesia Tahun 2013-2019}

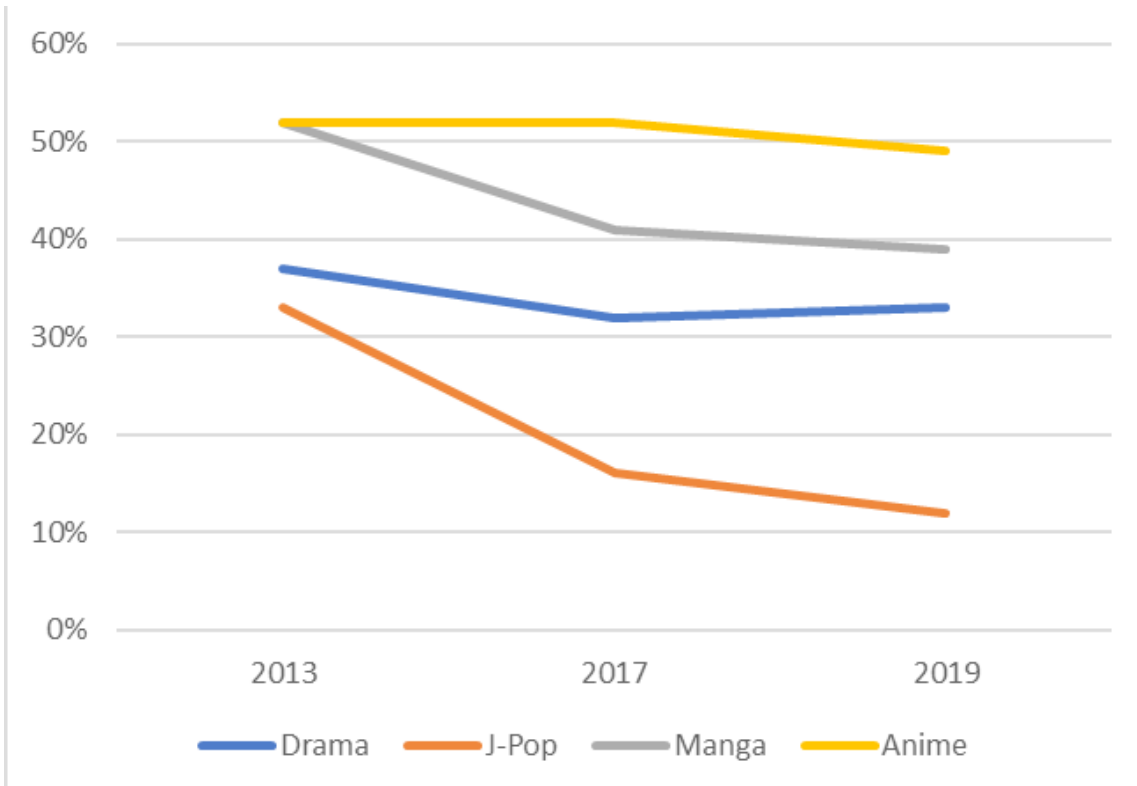

Sumber: Ministry of Foreign Affairs of Japan

Grafik 1 menunjukkan reliabilitas dan pentingnya kerja sama antara Jepang dan Indonesia menurut masyarakat Indonesia. Grafik 1 menunjukkan kenaikan dari tahun 2008 ke tahun 2013 setelah program Cool Japan diluncurkan, dan penurunan yang signifikan pada tahun 2019. Grafik 2 menunjukkan ketertarikan masyarakat Indonesia terhadap kebudayaan Jepang, yang meningkat secara signifikan sejak tahun 2013 setelah diluncurkannya program Cool Japan. Ini dapat menjadi indikator bagi kesuksesan diplomasi budaya Jepang di Indonesia. Grafik 3 menunjukkan tren budaya populer Jepang yang dibahas dalam tulisan ini (anime, manga, J-Pop, dan drama Jepang) berdasarkan grafik tahun 2013 - 2019.

\section{Anime dan Manga di Indonesia}

Anime adalah film animasi Jepang yang berbeda dari film animasi lainnya. Anime yang berasal dari kata animeeshon ini hadir dalam bentuk seasonal atau musiman. 30-40 anime dapat diproduksi setiap musimnya, berbeda dari kartun lainnya yang diproduksi secara tahunan (Muhammad 2019). Anime sukses meraih debut pada tahun 1963, yang ditandai dengan kesuksesan Astro Boy karya Osamu Tezuka dan kemudian diikuti oleh Speed Racer pada tahun 1967. Anime Jepang yang paling populer secara global di antaranya 
meliputi Pokemon, Doraemon, dan Captain Tsubasa. Bahkan, pada tahun 2004, anime Jepang ini mampu mengalahkan empat film Amerika, termasuk film-film Disney, di Academy Awards dalam kategori best animated feature (Pradika 2017).

Anime mulai masuk di Indonesia sekitar dekade 1970-an. Anime pertama yang disiarkan di stasiun televisi nasional TVRI berjudul Wanpaku Omukashi KumKum, namun anime baru mendapat perhatian yang masif pada akhir dekade 90-an ketika Doraemon, Saint Seiya, Samurai $X$, dan Digimon mulai disiarkan secara berkelanjutan di stasiun televisi swasta. Stasiun-stasiun televisi swasta yang paling sering menyiarkan anime meliputi RCTI, Indosiar, ANTV, TPI, dan Trans 7. Bahkan, hingga saat ini, Indosiar masih menyiarkan anime Jepang setiap hari Minggu pagi. Namun, penyiaran anime di stasiun televisi nasional bukanlah hal yang mudah. Berbagai macam sensor yang diberikan oleh KPI (Komisi Penyiaran Indonesia) sempat mengancam penyiaran anime di Indonesia. Berbagai alasan seperti adegan kekerasan dan vulgaritas anime dijadikan landasan untuk melarang penayangan beberapa anime, seperti Dragon Ball, One Piece, dan Detective Conan. Sensor inilah yang kemudian menghambat persebaran anime di Indonesia

Pada sisi lain, manga adalah komik khas Jepang yang mulai populer sejak 1970-an. Komik khas Jepang ini mendapat debut sejak 2000-an dengan popularitas berskala global. Tampilan manga yang bersifat tanpa gender (genderless) membuat komik khas Jepang ini lebih populer ketimbang komik terbitan Amerika. Kobo-chan adalah salah satu komik Jepang yang paling populer. Beberapa anime terkenal seperti Naruto dan Dragon Ball berawal dari debut manga, yang kemudian diproduksi dan ditayangkan di layar kaca. Persebaran awal manga di Indonesia pun tidak luput dari mispersepsi pemerintah Indonesia. Pada tahun 1995, manga dirazia dan dibakar karena dilihat sebagai produk yang mengandung pornografi dan kekerasan (Kartikasari 2018).

\section{J-Pop dan Drama Jepang di Indonesia}

Kehadiran $J$-Pop tidak begitu populer di kalangan remaja maupun anak-anak Indonesia. Dalam Grafik 3, dapat dilihat bahwa ketertarikan masyarakat Indonesia terhadap budaya populer jepang ini sangat rendah apabila dibandingkan dengan manga dan anime. Grafiknya pun selalu turun dari tahun ke tahun hingga mencapai hanya $12 \%$ pada tahun 2019. Hal ini bisa jadi disebabkan oleh dua faktor. Faktor yang pertama adalah keterlambatan dan kurangnya dukungan pemerintah di bidang industri musik Jepang. Faktor 
yang kedua adalah eksklusivitas industri musik Jepang yang hanya mengakomodasi girl group AKB48, yang menyebar ke Indonesia dengan nama JKT48. Eksklusivitas ini dapat dilihat dari sedikitnya jumlah dan variasi kelompok musik Jepang apabila dibandingkan dengan kelompok musik Korea Selatan yang sangat bervariasi (Effendi 2012). Sebagai akibat dari eksklusivitas tersebut, industri musik Jepang pada akhirnya tidak mampu menjangkau berbagai kalangan masyarakat, berbeda dari industri musik Korea yang tidak hanya menjangkau kalangan remaja, namun juga membuat ibu-ibu dan anak anak terpapar Korean Wave.

Sebelum drama-drama Korea Selatan membanjiri industri hiburan Indonesia, drama Jepang sudah lebih terlebih dahulu masuk ke Indonesia pada sekitar akhir dekade 90-an hingga awal 2000-an. Tokyo Love Story, Rindu Rindu Aizawa, dan Ordinary People adalah tiga drama yang sempat populer di Indonesia. Namun lagi-lagi, drama Jepang kalah pasar dari drama Korea sehingga mengalami penurunan pada tahun 2013 dan 2017, dan hanya mengalami sedikit peningkatan (3\%) pada tahun 2019. Hal ini mungkin dipengaruhi oleh alur cerita drama Jepang yang lebih bergenre komedi, sedangkan drama korea bergenre romansa, sehingga lebih menarik minat masyarakat Indonesia.

Budaya Jepang memang sempat menikmati popularitas tinggi di Indonesia pada awal 2000-an. Ini ditunjukkan dengan banyaknya komunitas otaku di Indonesia kala itu. Namun, keterlambatan pemerintah Jepang dalam menyadari hal ini membuat budaya populer Jepang mengalami penurunan tren dan digantikan dengan budaya populer Korea. Meski demikian, diseminasi budaya Jepang pada awal 2000-an tersebut mampu meningkatkan ketertarikan masyarakat Indonesia untuk belajar bahasa Jepang dan belajar di Jepang melalui program-program pertukaran pelajar yang secara intensif ditawarkan oleh pemerintah Jepang. Selain itu, popularitas makanan Jepang yang mencapai $52 \%$ persen juga menandakan keberhasilan diseminasi budaya melalui gastrodiplomacy.

\section{Diplomasi Budaya Korea di Indonesia}

Salah satu pengaruh budaya asing yang kuat di Indonesia berasal dari negara Korea Selatan dengan menggunakan Korean Wave atau Hallyu sebagai instrumen diplomasinya di Indonesia. Korean Wave awalnya hanya mendominasi di kawasan Asia Timur, namun kemudian mulai menyebar ke wilayah Asia Tenggara dan seluruh dunia (Jang dan Paik 2012). Korean Wave merupakan istilah yang digunakan untuk mendeskripsikan produk-produk kebudayaan 
Korea Selatan seperti acara televisi, seri drama, film, musik, tariantarian, mode, makanan, bahasa, produk kecantikan, dan video game (Jang dan Paik 2012). Sekumpulan produk budaya tersebut kemudian dipertunjukkan atau disajikan kepada masyarakat di negara lain dengan tujuan untuk membangun citra Korea Selatan yang modern.

\section{Hallyu atau Korean Wave}

Sebagai sebuah instrumen penyebaran kebudayaan, Hallyu merupakan produk yang dimanfaatkan oleh pemerintah Korea Selatan sebagai instrumen untuk membentuk citra Korea Selatan yang modern dan tidak tradisional. Hal ini sebenarnya berkaitan dengan upaya pemerintah Korea untuk membantu perkembangan ekonomi Korea Selatan, karena dalam usaha untuk memperkenalkan budaya Korea Selatan dan masyarakat Korea Selatan dengan cara yang ramah, diperlukan produksi produk-produk kebudayaan seperti yang disebutkan di atas. Hal ini berputar pada proses ekonomi yang memberikan ruang atau pasar bagi produsen produk kebudayaan di atas untuk terus berkreasi dan memenuhi kebutuhan pasar. Secara bersamaan, kreasi yang berkelanjutan ini yang juga akan meningkatkan permintaan terhadap produk budaya Korea Selatan. Oleh karena itu, dalam menjelaskan Korean Wave atau Hallyu, definisi yang tepat adalah pertumbuhan yang cepat pada industri kebudayaan Korea Selatan dan ekspor produk-produk budaya tersebut ke dunia internasional (Kim dan Jin 2016).

Korean Wave sebagai instrumen utama dalam mempromosikan kepentingan Korea Selatan di luar negeri tidak hanya merupakan agenda pemerintah Korea Selatan, namun di dalam prakteknya melibatkan banyak pihak swasta. Pada awalnya pemerintah Korea Selatan berperan besar dengan menyediakan kondisi yang memungkinkan bagi produksi kebudayaan untuk berlangsung, yang kemudian dimanfaatkan oleh pihak swasta seperti perusahaan dan individu. Setelah mendapatkan dampak positif dari berkembangnya Korean Wave, pemerintah Korea akhirnya memanfaatkan Korean Wave sebagai alat kebijakan luar negeri untuk membantu diplomasi publik dan kebudayaan Korea Selatan.

Proses produksi budaya Korea Selatan menjadi opsi sektor ekonomi alternatif bagi pemerintah Korea Selatan setelah terjadi krisis pada 1998. Hal ini dimulai dari perubahan kebijakan terhadap budaya yang terjadi pada masa pemerintahan Kim Young-sam (19931997), yang melihat potensi besar dari kebudayaan Korea Selatan dan potensi kebudayaan tersebut untuk menjadi sumber GDP. 
Pandangan ini juga ditegaskan dalam pemerintahan Kim Dae Jung (1998 - 2002) dengan dibangunnya infrastruktur dan sarana yang membantu industri kebudayaan domestik. Industri kebudayaan yang pada awalnya ditujukan untuk membuka alternatif bagi pendapatan nasional Korea Selatan ini kemudian berubah menjadi instrumen diplomasi pemerintah Korea Selatan, yang juga berguna untuk meningkatkan citra nasional Korea Selatan dan mempermudah hubungan dengan negara lain.

Proses perubahan upaya promosi menjadikebijakanluar negeri Korea Selatan dalam diplomasi budaya terjadi di bawah kepemimpinan Lee Myung-bak dengan dicanangkannya "complex diplomacy" dan "value diplomacy", yang bertujuan untuk meningkatkan diplomasi publik dan diplomasi budaya Korea Selatan (Jang dan Paik 2012). Hal ini ditandai dengan ditingkatannya anggaran untuk diplomasi publik dan dijadikannya Hallyu sebagai media utama diplomasi publik tersebut. Maka dari itu, dalam praktiknya Kementerian Luar Negeri Korea Selatan telah melakukan riset statistik terhadap status Hallyu di negara-negara di dunia, dan kemudian menyediakan dukungan serta bantuan terhadap klub-klub penggemar Hallyu untuk menyelenggarakan acara-acara promosi kebudayaan Korea (Ministry of Foreign Affairs Republic of Korea 2013).

Penyebaran Hallyu juga terjadi di Indonesia sejak tahun 2002, setelah penyelenggaraan Piala Dunia di Jepang dan Korea Selatan. Siaran Piala Dunia ditayangkan di televisi nasional Indonesia, yang kemudian membuka pintu bagi serial drama Korea untuk ditayangkan di Indonesia. Serial drama Korea (K-Drama) pertama yang ditayangkan di Indonesia adalah Mother's Sea di stasiun televisi Trans TV, yang kemudian diikuti dengan disiarkannya Endless Love oleh Indosiar pada tahun yang sama. Hal ini kemudian terus berkembang karena menurut data yang diambil oleh Viva Newstime di aplikasi Tribe Indonesia, penonton Indonesia menghabiskan waktu rata-rata 76 menit dalam sehari untuk menonton tayangan Korea Selatan pada 2017 (Astuti 2017). Selain ditayangkan melalui televisi nasional, beberapa aplikasi penyedia layanan video on demand (VOD) di Indonesia, seperti iFlix, VIU, dan Tribe, juga menawarkan drama Korea (Khoiri 2018).

K-Drama menjadi salah satu pilihan penonton Indonesia, karena drama-drama Korea Selatan cenderung dikemas lebih baik ketimbang drama Indonesia. Drama Korea Selatan pada umumnya diangkat dengan tema yang jelas dan penulisannya didasarkan pada riset mendalam. Dari segi durasi, drama Korea dikemas dalam 16 hingga 20 episode, yang berarti penyampaian cerita dilakukan 
dengan padat dan jelas. Alur cerita drama Korea juga tidak melebar jauh seperti sinetron Indonesia pada umumnya. Cerita yang pada umumnya berada dalam genre romance dan alur yang santai menjadi daya tarik tersendiri bagi drama Korea di mata penonton Indonesia (Salam et al. 2012). Masuknya K-Drama juga diikuti dengan masuknya industri musik Korea Selatan (K-Pop) yang juga mewarnai pasar musik di Indonesia. Semenjak tahun 2011, industri K-Pop semakin berpengaruh di Indonesia dan pada tahun 2012 konser artis Korea Selatan Super Junior dilaksanakan di Indonesia untuk pertama kalinya. Penyelenggaraan konser ini menandakan besarnya peminat musik K-Pop di Indonesia. Hal ini menjadikan Indonesia salah satu negara yang wajib dikunjungi oleh artis-artis Korea di dalam tur-tur album mereka (Dante 2017).

Menurut wawancara yang dilakukan oleh Dante (2017) terhadap pengamat musik sekaligus Editor in Chief majalah Rolling Stone Adib Hidayat, tingginya tingkat kegemaran masyarakat Indonesia terhadap band dan musisi Korea Selatan disebabkan oleh visual dari performa musisi-musisi Korea Selatan. Tampilan fisik yang berkarakteristik orang-orang Asia Timur (berkulit putih) menjadi faktor utama preferensi masyarakat Indonesia terhadap musisimusisi Korea Selatan. Kemampuan menampilkan lagu yang diiringi dengan tarian yang moderen serta visualisasi yang sangat baik juga menjadikan musisi Korea Selatan menarik di mata masyarakat Indonesia (Dante 2017). Hal ini terutama terjadi pada boy band, yang merupakan komoditas industri K-Pop yang paling dinikmati di Indonesia.

\section{Grafik 4. Minat Pencarian Web dari Kata Kunci K-Pop, K-Drama, Budaya Korea, dan Korea Selatan di Indonesia}

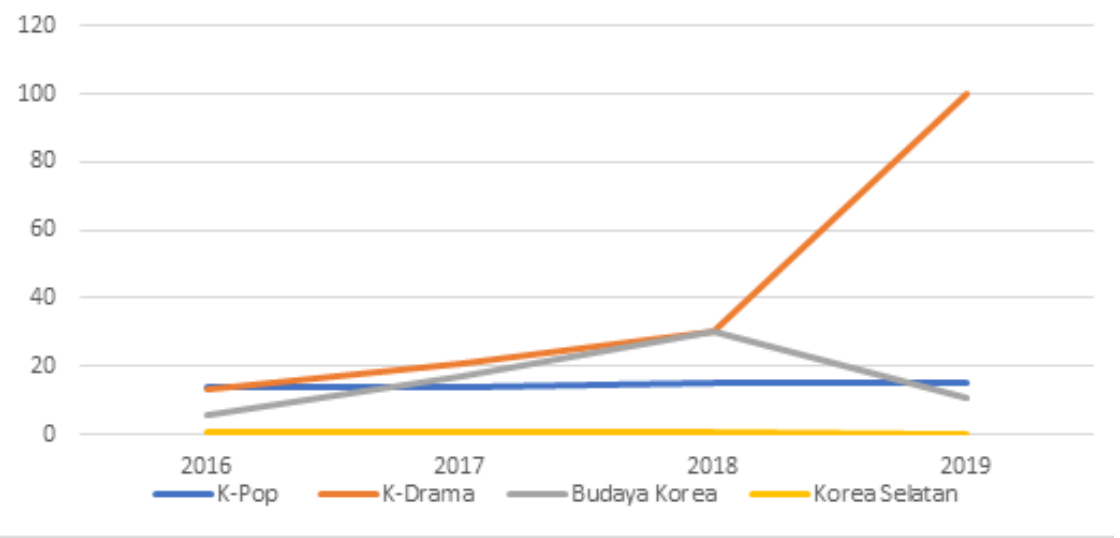

Sumber: Google Trends 


\section{Hallyu dalam Diplomasi Publik Korea Selatan}

Masuknya pengaruh K-Drama dan K-Poptidak hanya menjadi agenda industri kebudayaan Korea Selatan, tetapi juga menjadi instrumen pemerintah Korea Selatan untuk menyebarkan kebudayaan Korea Selatan. Seringkali serial drama Korea menampilkan ilustrasi kehidupan masyarakat Korea, khususnya tata cara berpakaian, makanan, dan produk-produk yang dikonsumsi sehari-hari. Hal ini menjadi peluang untuk menumbuhkan pengaruh terhadap gaya hidup penonton (Salam et al. 2012). K-Drama menjadi peluang besar bagi Korea Selatan untuk mempromosikan kebudayaannya dan akhirnya meningkatkan rasa ingin tahu penonton tentang kebudayaan Korea Selatan. Selain minat yang distimulasi oleh drama Korea, hal lain yang mendukung adalah pengaruh selera fashion yang diberikan oleh para musisi K-Pop terhadap penggemarnya. Busana yang dikenakan oleh para musisi tersebut menjadi inspirasi berpakaian remaja-remaja Indonesia. Selain itu, hal-hal seperti tata rias dan produk perawatan kulit yang digunakan juga menjadi pilihan masyarakat Indonesia. Hal ini sangat sesuai dengan kepentingan industri-industri besar di Korea Selatan, khususnya industri kosmetiknya yang merupakan salah satu yang paling dominan di dunia.

Masuknya K-Drama dan K-Pop membuka peluang bagi pengaruh terhadap preferensi penonton K-Drama dan penggemar K-Pop di Indonesia dalam memilih produk sehari-hari. Hal ini ditandai dengan semakin tingginya penggunaan produk-produk Korea Selatan di Indonesia, seperti kosmetik dan makanan. Beberapa brand terkenal, seperti Nature Republic, Laneige, dan Innisfree, merupakan beberapa brand kosmetik Korea Selatan yang telah mendominasi pasar di Indonesia. Selain itu, produk-produk dari Samyang juga berhasil masuk ke toko-toko lokal Indonesia karena telah menjadi kesukaan masyarakat Indonesia (Setiawan 2018). 


\section{Grafik 5. Popularitas K-Drama Indonesia 2019}

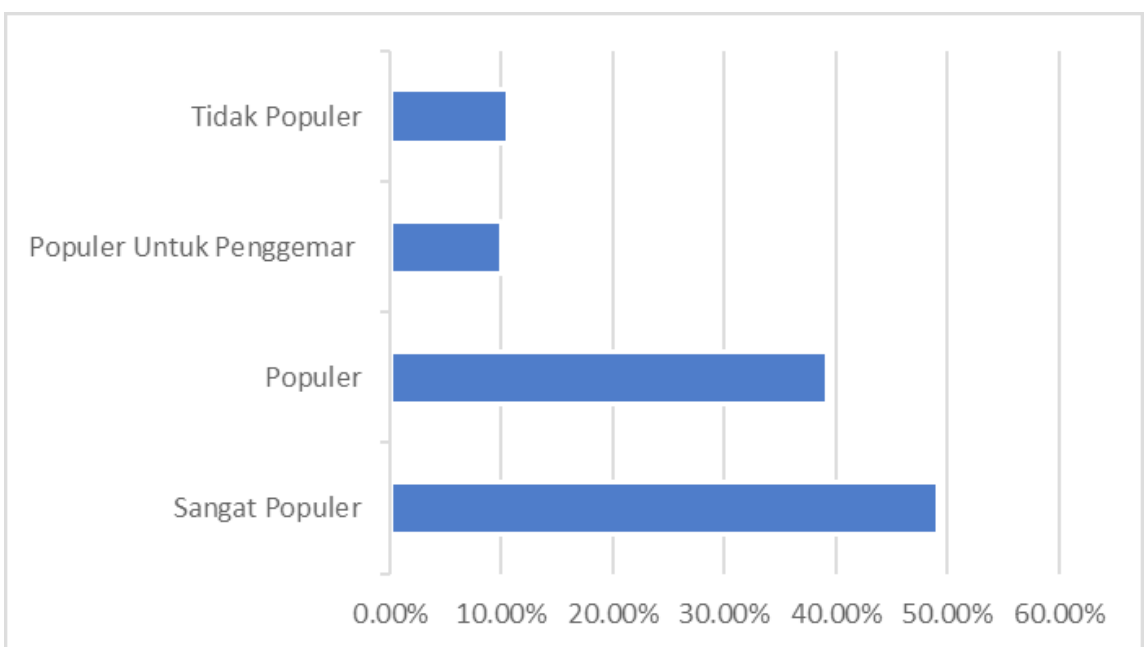

\section{Grafik 6. Negara dengan Jumlah Penonton K-Pop Tertinggi 2019}

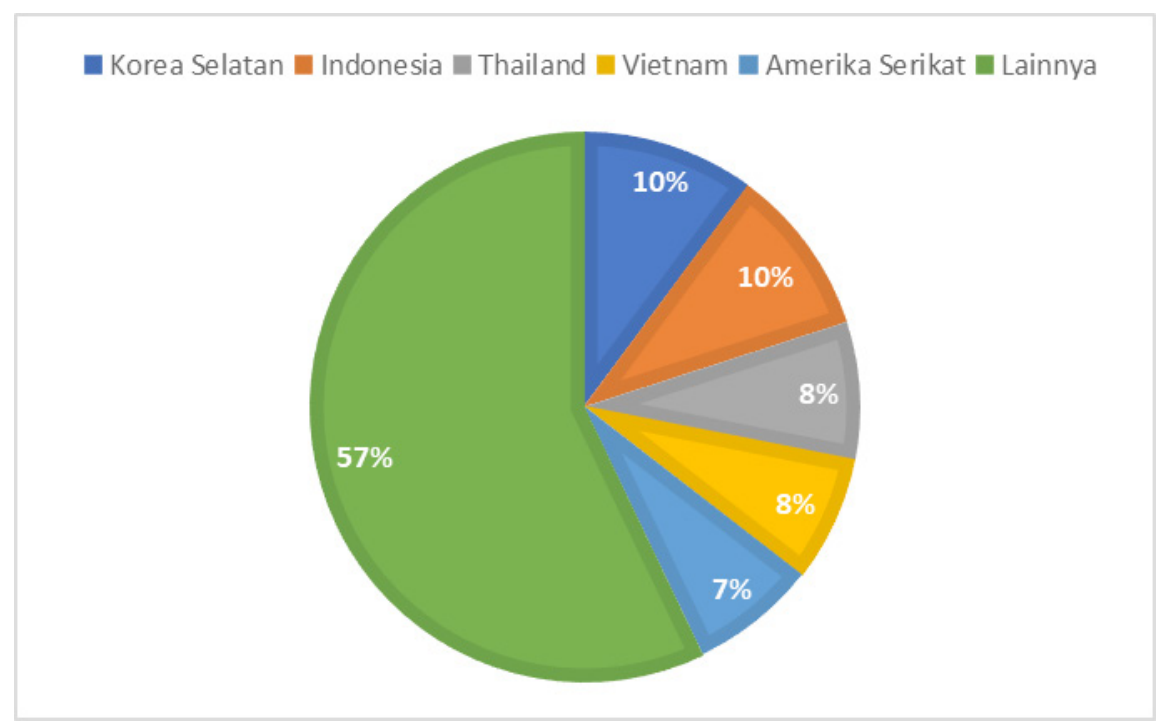

Sumber: Blip dalam Jung dan Lee 2019.

Diseminasi kebudayaan Korea Selatan melalui K-Drama dan K-Pop menjadikan kebudayaan Korea lebih dikenal oleh masyarakat Indonesia. Hal ini ditunjukkan dengan semakin tingginya minat masyarakat Indonesia terhadap produk-produk kebudayaan Korea Selatan. Hasil penelitian yang dilakukan oleh BLIP melalui YouTube Insights pada 2019 menyatakan bahwa dari 90 juta penggemar 
K-Pop di dunia, 9,9\% berada di Indonesia. Angka ini menempatkan Indonesia pada posisi jumlah penggemar K-Pop terbesar kedua di dunia (Jung dan Lee 2019). Selain itu juga terdapat peningkatan sebesar 3,3\% terhadap impor makanan Korea dan consumer goods dari Korea Selatan.

Selain terhadap produk-produk kebudayaan Korea Selatan, peningkatan minat masyarakat juga ditunjukkan di dalam tingginya minat warga Indonesia untuk berkunjung ke Korea Selatan. Hal ini ditunjukkan dengan peningkatan pada kunjungan warga negara Indonesia ke Korea Selatan setiap tahunnya. Menurut Kementerian Luar Negeri Indonesia, jumlah WNI yang mengunjungi Korea Selatan pada 2018 adalah 249.067 orang dengan peningkatan 7,9\% dari tahun sebelumnya. Hal ini juga akhirnya menunjukkan keberhasilan diplomasi budaya yang dilakukan oleh Korea Selatan melalui Hallyu dalam meningkatkan minat masyarakat Indonesia untuk mengeksplorasi kebudayaan Korea Selatan.

\section{Komparasi Diplomasi Budaya Jepang dan Korea Selatan di Indonesia}

Berdasarkan penjabaran dalam sub-bab sebelumnya, pada bagian ini penulis mengkomparasikan diplomasi budaya yang dilakukan oleh Jepang dan Korea Selatan di Indonesia dan melihat transisi pada popularitas diplomasi budaya Jepang dan Korea Selatan di Indonesia. Budaya Jepang mulai masuk di Indonesia sejak akhir 1970-an, namun program Cool Japan baru diluncurkan pada tahun 2010, yang sebelumnya dimulai dengan penunjukan Doraemon sebagai duta anime Jepang pada tahun 2008. Diplomasi budaya Jepang dilakukan melalui pop-culture seperti anime, manga, J-pop, dan drama serial Jepang. Anime sempat mendapatkan perhatian yang masif di awal waktu tayangnya. Tidak hanya anime, manga memiliki tingkat perhatian yang serupa. Namun, penyebaran budaya Jepang di Indonesia, terutama anime dan manga sempat terkendala dengan masalah sensor yang dilakukan oleh KPI.

Selain itu, J-Pop yang mewakili sektor musik Jepang juga berhasil masuk dan mewarnai pasar musik Indonesia. Namun sayangnya, J-Pop tidak terlalu populer di kalangan remaja karena beberapa faktor, yakni kurangnya dukungan pemerintah dan eksklusivitas industri musik Jepang. Karena eksklusivitas ini, industri musik jepang pada akhirnya tidak mampu menjangkau berbagai kalangan masyarakat. Pada sisi lain, Korea Selatan melalui Hallyu memasuki Indonesia pada tahun 2002, saat budaya Jepang sedang populer di Indonesia. Oleh karena itu, di awal 2000-an, budaya Korea Selatan 
tidak begitu masif terdengar di Indonesia, meskipun memang sudah terdapat beberapa serial drama Korea Selatan yang tayang di televisi Indonesia. Jika dilihat dalam tren yang ada dalam Grafik 4, Korean Wave mulai menunjukkan tren positif di Indonesia setelah tahun 2017. Meskipun demikian, mungkin Korean Wave muncul lebih awal dari estimasi ini.

Selain dari sektor film, ternyata budaya musik Korea juga telah mewarnai pasar musik di Indonesia sejak tahun 2011. K-Pop semakin berpengaruh di Indonesia ketika Super Junior mengadakan konser pertamanya di Indonesia. K-Pop ternyata juga menginspirasi pasar musik Indonesia dengan menciptakan banyak boy band dengan konsep yang hampir sama dengan K-Pop, yakni bernyanyi sambil diiringi tarian. Penggemar K-Pop di Indonesia cukup banyak, sebagaimana ditunjukkan oleh hasil penelitian yang dilakukan BLIP (dalam Jung dan Lee 2019) melalui YouTube Insights pada 2019. Penelitian ini menunjukkan bahwa dari 90 juta penggemar K-Pop di dunia, 9,9\% berada di Indonesia. Dengan demikian, diplomasi budaya Jepang dan Korea Selatan dapat disajikan dalam tabel sebagai berikut:

\section{Tabel 1. Perbandingan Diplomasi Budaya Jepang dan Korea Selatan di Indonesia}

\begin{tabular}{|c|c|}
\hline Jepang & Korea Selatan \\
\hline Dimulai sejak akhir 1970-an & Dimulai sejak awal 2000-an \\
\hline $\begin{array}{c}\text { Budaya yang dipasarkan: drama } \\
\text { serial Jepang, anime, manga, dan } \\
\text { J-pop }\end{array}$ & K-Pop, drama Korea \\
\hline $\begin{array}{c}\text { Cool Japan diperkenalkan pada } \\
\text { tahun 2010 }\end{array}$ & $\begin{array}{c}\text { Hallyu diperkenalkan pada } \\
\text { awal 2000-an }\end{array}$ \\
\hline $\begin{array}{c}\text { Pernah mengalami resistensi } \\
\text { signifikan dari pemerintah dan } \\
\text { terkendala dengan sensor }\end{array}$ & $\begin{array}{c}\text { Tidak pernah mengalami resistensi } \\
\text { yang signifikan dari pemerintah }\end{array}$ \\
\hline $\begin{array}{c}\text { Mengalami tren negatif pasca tahun } \\
\text { 2013 }\end{array}$ & $\begin{array}{c}\text { Mengalami tren positif pasca konser } \\
\text { pertama Super Junior di Indonesia } \\
\text { pada tahun 2011 }\end{array}$ \\
\hline
\end{tabular}

\section{Kesimpulan}

Budaya Jepang memang sempat memiliki popularitas tinggi di Indonesia pada awal 2000-an. Ini ditunjukkan dengan banyaknya komunitas otaku di Indonesia kala itu. Namun, program diplomasi budaya Jepang yang terlambat menyadari hal ini menyebabkan penurunan tren pada pop culture Jepang sejak tahun 2013. 
Pengaruh budaya Jepang di Indonesia kemudian digantikan dengan budaya populer Korea. Meski demikian, diseminasi budaya Jepang sejak akhir 1970-an tersebut mampu meningkatkan ketertarikan masyarakat Indonesia untuk belajar Bahasa Jepang dan belajar di Jepang melalui program pertukaran pelajar yang secara intensif ditawarkan oleh pemerintah Jepang. Sementara itu, Korea Selatan melalui Hallyu sukses menarik perhatian masyarakat Indonesia dengan perfoma boy band dan serial drama yang tidak hanya menarik perhatian masyarakat Indonesia di bidang perfilman dan musik, tetapi juga pada bidang kuliner dan pariwisata. Dengan memaparkan perkembangan diplomasi budaya Jepang dan Korea Selatan di Indonesia secara kronologis, penelitian ini menyediakan landasan bagi penelitian-penelitian lain di masa depan yang hendak menganalisis faktor-faktor yang memicu transisi dari dominasi produk-produk kebudayaan Jepang ke produk-produk kebudayaan Korea Selatan di Indonesia. 


\section{Daftar Pustaka}

\section{Buku}

Azwar, Saifuddin, 1998. Metode Penelitian, edisi pertama. Yogyakarta: Pustaka Pelajar.

Goff, Patricia M., 2013. "Cultural Diplomacy," dalam Cooper, A. F., J. Heine, dan R. Thakur (eds.), The Oxford Handbook of Modern Diplomacy. Oxford: Oxford University Press.

Nye, Joseph S., 2010. The Future of Power. New York: Public Affairs.

Rana, Kishan S., 2011. $21^{\text {st }}$ Century Diplomacy: A Practicioner's Guide. New York: Bloomsbury Publishing USA.

Tuch, Hans N., 1990. Communicating with the World: US Public Diplomacy Overseas. New York: St. Martin's Press.

\section{Artikel Jurnal}

Effendi, Tonny Dian, 2012. "K-pop and J-pop Influences to University Students in Malang, East Java - Indonesia: A Comparative Public Diplomacy Studies," Andalas Journal of International Studies, 1(2): 182-198.

Ito, Kinko, 2005. "A History of Manga in the Context of Japanese Culture and Society," The Journal of Popular Culture, 38(3): 456.

Jang, Gunjoo dan Won K. Paik, 2012. "Korean Wave as Tool for Korea's New Cultural Diplomacy," Advances in Applied Sociology, 2(3): 196-202.

Han, Seungik, 2015. "Indonesia, Japanophile: Japanese Soft Power in Indonesia," GSCIS Singapore: 1-10.

Kartikasari, Wahyuni, 2018. "The Role of Anime and Manga in Indonesia-Japan Cultural Diplomacy," Tsukuba Gakuin University Press, 13: 41-47.

Kim, Tae Young dan Jin D.Y., 2016. "Cultural Policy in the Korean Wave: An Analysis of Cultural Diplomacy Embedded in Presidential Speeches," International Journal of Communication, 10: 5514-5534. 
Nye, Joseph S., 2008. "Public Diplomacy and Soft Power," The Annals of the American Academy of Political and Social Science, 616 (1): 94-109.

Salam, Ivan, Susie Perbawasari, dan Kokom Komariah, 2012. "Hubungan antara Terpaan Drama Korea di Televisi dengan Gaya Hidup Penonton," eJurnal Mahasiswa Universitas Padjajaran, 1(1): 24.

\section{Laporan Penelitian}

Cull, Nicholas John, 2009. "Public Diplomacy: Lessons from the Past," CPD Perspectives on Public Diplomacy. Los Angeles: Figueroa Press.

Pradika, Dikta, 2017. POP-CULTURE IN PUBLIC DIPLOMACY: ANIME AND MANGA AS JAPAN'S SOFT POWER IN INDONESIA (2004 - 2013). Disertasi. Jakarta: President University.

Setiawan, Hendra, 2018. Hubungan antara Sikap Individu dan Sikap Lingkungan terhadap Budaya Korea pada Keputusan Pembelian: Minat Beli terhadap Produk Merek Kosmetik Korea sebagai Pemediasi. Disertasi. Yogyakarta: STIE YKPN.

\section{Sumber Elektronik}

Astuti, Lutfi D.P., 2017. "Drama Korea Menjadi Tayangan Favorite Generasi Z dan Milennial," Viva, 25 Oktober [Daring]. Dalam https://www.viva.co.id/showbiz/serial/970591-dramakorea-jadi-tayangan-favorit-generasi-z-dan-millennial [diakses 15 Maret 2020].

ICD, t.t. "What is Cultural Diplomacy?" [Daring]. Dalam http://www. culturaldiplomacy.org/index.php?en_culturaldiplomacy [diakses 26 Maret 2020].

Khoiri, Agniya, 2018. "Drama Korea Punya Potensi Pasar Besar di Indonesia," CNN Indonesia, 18 Maret [Daring]. Dalam https://www.cnnindonesia.com/ hiburan/20180317185702-220-283840/drama-koreapunya-potensi-pasar-besar-di-indonesia [diakses 15 Maret 2020]. 
Jung, Joo-ri dan Lee Ji-hae, 2019. "Map Showing K-Pop’s Popularity by Global Region Released," Korea.net, 27 Agustus [Daring]. Dalam http://www.korea.net/NewsFocus/Culture/ view?articleId $=174587$ [diakses 16 Maret 2020].

Muhammad, Fikri, 2019. "Fandomnya Banyak, Yuk Melihat Kembali Perjalanan Anime di RI," CNBC Indonesia, 16 Maret [Daring]. Dalam https://www.cnbcindonesia.com/ lifestyle/20190316114109-33-61045/fandomnya-banyakyuk-melihat-kembali-perjalanan-anime-di-ri [diakses 20 Maret 2020].

Dante, Valerie, 2017. "Memahami Demam K-Pop di Indonesia," Rappler, 15 September [Daring]. Dalam https://www. rappler.com/world/bahasa-indonesia/memahami-demamk-pop-indonesia [diakses 15 Maret 2020].

Stanislaus, Warren A., 2018. "Japan is Using Cultural Diplomacy to Reassert Its Place in the World - But Is the Message Too Exclusive?" The Conversation, 12 November [Daring]. Dalam https://theconversation.com/japan-is-using-culturaldiplomacy-to-reassert-its-place-in-the-world-but-is-themessage-too-exclusive-106463 [diakses 19 Maret 2020].

Wood, Jennie, 2017. "Manga and Anime: The Japanese Invasion," Infoplease, 28 Februari [Daring]. Dalam http://www. infoplease.com/entertainment/books/manga-anime.html [diakses 25 Maret 2020].

\section{Publikasi Resmi}

Diplomatic Bluebook, 2017. Tokyo: Ministry of Foreign Affairs of Japan.

Ministry of Foreign Affairs of the Republic of Korea, 2013. "Overview" [Daring]. Dalam http://www.mofa.go.kr/eng/ wpge/m_5664/contents.do [diakses 15 Maret 2020]. 